\title{
Social Capital of Madura Barbers in Makassar, South Sulawesi
}

\author{
Jumadi $^{1 凶}$ \\ ${ }^{1}$ Universitas Negeri Makassar, Indonesia
}

DOI: http://dx.doi.org/10.15294/komunitas.v8i2.6219

Received : 2016; Accepted: 2016; Published: 30 September 2016

\begin{abstract}
This study aims at understanding and analyzing social capital and human capital of Madura barbers in Makassar. This research was qualitative with case study approach. The informants were Madura barbers in Makassar selected using snowball sampling focused on social capital and human capital issues. Researcher acted as research instrument who collected data through observation, interview, and documentation then analyzed them by reducing, presenting, and developing the data and validated the data through observation extension technique, perseverance, member check, and triangulation. The researcher found several things. People have given trust toward Madura barbers. Barbers uphold the norms as Madurese. They form kinship network through organization. Human capital of Madura barbers in Makassar is based on knowledge gained informally from environment and parents. Experience is gained hereditary with satisfactory results. They need to improve their business and increase the number of customers with skills. They are creative to followthe dynamics of hairstyle. There is innovation regarding shaving tools from gothok to clipper.
\end{abstract}

Keywords: human capital; Madurese Barbers; social capital

\section{INTRODUCTION}

Madura population in 2000 was 3.2303 million people. It is more or less than the population of Madura in 1990, namely 4,015,972 people. Meanwhile, the population of Madurese Ethnic in East Java province is 6,281,058 inhabitants, and throughout Indonesia, the population is 6,771,727 inhabitants (Wiyata 2013). The data show that the population of Madura has decreased during the ten years namely from 1990 to 2000 since most or more than half of the Madurese ethnic are not on the island of Madura. It also shows a unique social phenomenon in which mobility rate is very high.

The census conducted in 2000 shows that Madurese ethnic spread in 30 provinces in Indonesia. The largest population of Madurese ethnic is in East Java, 6,281,058 people followed by West Kalimantan $(203,612)$, Central Kalimantan $(62,228)$, East
Kalimantan $(30,181)$ and South Kaliman$\tan (36,334)$. The smallest concentration is in Gorontalo Province (40) (Wiyata 2013). Meanwhile, Madurese in Makassar South Sulawesi reached 460 head of the family. The migration of Madurese has lasted long enough in the various regions in Indonesia. The conditions of geographic (which is arid), economic, and socio-cultural factors are the extensive network of kinship in Madura community. There is a perception in Madurese community that if you want to search for property or livelihood go to Java (Shamsuddin 2007). Migration is a life choice for Madurese, even according to de Jonge (1989) the regional distribution of their migration is more widely, not only in Java, especially the eastern part which has lasted since the colonial period but also other areas such as Kalimantan, even in South Sulawesi, especially in Makassar. Madurese wan- 
der to seek new livelihoods because poverty and unemployment brought Madura to be one of the poorer areas in East Java province (Muthmainnah 1998).

Madurese who has a high work ethic, and who do not give up easily in the face of life is one of the main capitals for immigrants (Rifai 2007; Wiyata 2013). Life orientation of Madurese is more oriented on the work than property (Djafar 2010). They are easily recognizable because of their work in the informal sector. In addition, they are often associated with a variety of jobs such as barbers, sate or soto seller, and scrap metal buyers. The Barber has become the identity for Madurese in Makassar. Almost in every corner of the city in Makassar, there is Madura barber. Becoming a barber is not only for economic value, but also contains a socio-cultural dimension in the Madurese immigrants' life (Rifai 2007).

Based on data from Indonesian Kinship Association of Madura called PERKIM in Makassar, it is showen that in 2013, 141 Madura barbershops were spreading across 27 regions in Makassar. Madura ethnic barbers in Makassar continue to experience growth in the number of the barbershop. The problem is that what kind of social capital and human capital owned by the Madurese so that they can survive in Makassar. The researcher would like to know whether they have actual and potential possession (Bourdieu 1986), aspects of social structure (Coleman 1988) or the value of mutual trust, networks, norms, or social trust (Putnam 1993). Furthermore, the human capital can include knowledge, experience, skills, creativity, and innovation. Schultz as the experts of human capital theory explains that human capital is reflected in the form of knowledge, ideas, creativity, skill, and labor productivity. In addition, Berger and Luckmann (1990) reveal that knowledge is that the certainty of phenomena is real and has specific characteristics, related to such matters which will be a parameter to determine the social capital and human capital of Madurese barber in Makassar.

\section{RESEARCH METHOD}

This research was a qualitative research with case study approach, and it was intended to explore and analyze the social capital and human capital of Madurese barber in Makassar. Emic perspective was used to collect data based on what was said, felt, and made by the informants in the field. It was not according to what the researchers thought. The informants were Madura barbers consisting of elders or community leaders of Madura who have high influence and experience as well as the employee of the Madura barbershops. The informants were selected Table 1. The lists of Informants

\begin{tabular}{|c|c|c|c|c|}
\hline No & Informants Name & Age & Jobs & Notes \\
\hline 1. & Hasan & 42 & Barber shop employee & $\begin{array}{l}\text { Pangkas Rambut "Hasan” Madura Jl. } \\
\text { Dg. Tata Makassar }\end{array}$ \\
\hline 2. & Ahmad Rasyidi & 54 & $\begin{array}{l}\text { Community Leader of } \\
\text { Madura }\end{array}$ & Jl. Kokolojia Lr. 1 Makassar \\
\hline 3. & Samiin & 54 & Barber shop employee & $\begin{array}{l}\text { Pangkas Rambut SINAR. Jl. Tamalate } \\
\text { Makassar }\end{array}$ \\
\hline 4. & H. Suaib & 58 & Barber shop employee & $\begin{array}{l}\text { Gunting Rambut SEJATI Jl. Sultan } \\
\text { Alauddin Makassar }\end{array}$ \\
\hline 5. & UdinMutiara & 52 & Owner/Businessman & $\begin{array}{l}\text { Pangkas Rambut MUTIARA } \\
\text { BARBERSHOP Jl. Jenderal Sudirman } \\
\text { Makassar }\end{array}$ \\
\hline 6. & Suhairi & 67 & Barber shop employee & $\begin{array}{l}\text { Gunting Rambut SETIA Jl. Irian } \\
\text { Makassar }\end{array}$ \\
\hline 7. & Slamet & 58 & $\begin{array}{l}\text { Administrator of PERKIM/ } \\
\text { Barber shop employee }\end{array}$ & BTN Pao-Pao Makassar \\
\hline 8. & Sudirman & 51 & Barber shop employee & Jl. Cenderawasih Makassar \\
\hline 9 . & Salahuddin & 38 & Barber shop employee & $\begin{array}{l}\text { Gunting Rambut KRAMAT Jl. Gunung } \\
\text { Lompobattang Makassar. }\end{array}$ \\
\hline
\end{tabular}


using snowball sampling techniques. The information about the informants can be seen in table 1.

The research focuses on the ownership of social capital and human capital of Madurese barber in Makassar. Human capital includes knowledge, experience, skills, creativity, and innovation. Social capital includes beliefs, norms, and networks. The researcher as research instrument adapted and interacted with the informants for the purpose of collecting data and feeling the sense of understanding.

The data were collected through observation in which the researcher must reobserve the problems and research objectives and develop his own needs in the field (Bunging 2011). The data were also collected through in-depth interviews and documentation. Data were analyzed by using three steps namely data reduction, data presentation, and development or interaction model of Miles and Huberman (1984). The data were then validated by using an extension of observation, improving endurance, holding member check, and performing triangulation (Moleong 1989).

\section{RESULTS AND DISCUSSION}

\section{Social Capital of Madura Barber in Makassar}

Social capital according to Bourdieu (Parwitaningsih 2010, p.28) is a collection of sources of actual or potential associated with ownership of a network that lasts a long time, of one or more institutionalized relationship which is mutually agreed and recognized. Social capital can be defined as the social construction of social interaction of individuals in building social forces collectively to solve various social problems. Social capital can be in the form of tools constructed by individuals for a common goal. For example, Madurese in Makassar who became barbers are the social capitals that are awakened individually in building a social force. Social capital as a barber has built social interaction with various community groups in order to create a social force despite being overseas. Madurese in Makassar who works as
Barber are mostly from Bangkalan Madura while the Madurese who are from the center is more pursue their work in their own area (Ahmad Rasyidi interviewed on February $15,2016)$. Social capital is an aspect of social structures that facilitates individual action. The value of trust among community members refers to capabilities that arise from the general trust in society (Coleman 1998; Putnam 1993; Fukuyama 2005). Social capital is a social institution that involves trust, norms, and networks for social collaboration. Measuring social capital owned by the Barbers in Makassar can be viewed from three aspects namely trusts, norms, and networks.

Aspects of trust: it is the social capital that is owned by the barber that can be trusted by its customers. Trust becomes a strong part to form good social capital to create a harmonious and dynamic relationship between the barbers and their customers. The strong social capital should be supported by the high level of trust with adhesiveness of social relationships and the capacity to build a broad network (Puspitasari 2012, p.78). The results showed that the barbers build their trust through work ethic. The Madurese have characteristics, beliefs, attitudes, views, guidelines or benchmarks to work. The work as a barber is related to trust, from my grandfather to my father, they were a barber and therefore I also become a barber (UdinMutiara, interviewed on February 18,2016$)$. It is a responsibility to continue this job as a barber from one generation to next generation since this job is very good and lawful (Sudirman, interviewed on February 18, 2016). This view is in line with the results of research conducted by Kamarni (2012, p.48) in which he found that social capital is attached to a set of social relations among people within a social group. The relationship in the community can be productive if there is an agreed set of values and there is a mutual trust.

They stated that the work is a part of worship (it can be seen in Madura barber shops that always have an image of clerics from Madura displayed in the barber shops). They also assumed that the op- 
portunity to work is a grace of God so that it must be practiced wholeheartedly. Their spirit in working is reflected in the life philosophy of Madurese in finding sustenance, such as KarKarkarcolpe (they can only eat after they work) or Abantal omba 'asapo' wind (cushioned the waves and the wind covered) and abarenteng (spirit and optimism in the works).

The factor of local trust of Madurese is also imposed in Makassar. Values and religious norms or beliefs which are held are reflected in the social life of the community (Pontoh 2010, p.128). Madurese barbers in Makassar assume that shaving business must be based on work ethic and principles that must be inculcated in the young generation that includes perseverance in doing business. Therefore, the business can provide the best service and manners or decorum. Aspects of trust become a major component of social capital in the form of partnerships and networks which are based on the establishment of a mutual trust among the community (Pranadji 2006, p.192).

Aspects of norm: for the Madurese barbers, the norm became a major principle in the business. They are very obedient to the norms prevailing in society in a way to uphold and obey the rules that have been agreed. The barbers do their job based on religious values, cultural values, and the values of everyday life. Madura local norms are kept, and it is not only with fellow Madurese in Makassar, but also with the people of Makassar, especially customers and their neighbor. The norm values are kept to build public trust. Based on the results of the study, it is found that the barbers respect for parents, the opinions of others, and the norm for a healthy life. They do not suspect the norm of other people, and they uphold the norm to be together and live together with other people. They are completely aware of his position as immigrants so that they have to obey the rules prevailing in society, particularly the rules on a particular social entity.

The aspect of Networking: barbers develop a good business network among the Madurese and the surrounding communities. Madurese in Makassar build social networks through kinship, and there is an organization called PERKIM in Makassar. This organization is a social nature, and it is a place for Madurese in Makassar for sharing, including through social meeting to perform recitals and taking care of social problems of Madurese. The social network is conducted for the development of their barbershops. They pursue and develop their business. "Initially I was only invited by the family to Makassar, later when I arrived in Makassar, I learn to be a barber" (Suhairi, interviewed on February 20, 2016). Nevertheless, the aspect of networking also noted various problems faced by the barbers. First, they have limited capital. Second, they need a place (rent). Third, they require shaving kit (scissors, mirrors, chairs, and tables) since most of Madurese in Makassar do not have their own house. Therefore, they rent a house for a period of time. In addition, they also need a strategic place to build their barbershops. Social capital through a network of PERKIM organization can strengthen the capacity of barbers. According to Syahra (2003, p.11), social capital can strengthen the capacity of organization which becomes the media of the economy. Social capital is an asset in the economic development of Madura Barber through the formed organization namely PERKIM. According to Hasan, (interviewed on March 12, 2016) PERKIM organization that collects Madurese in Makassar had existed since 1950. It was originally named Sinoman Madura, and it was founded by elders and community leaders such as H. Syukur, H. Ibrahim, and $\mathrm{H}$. Umar. This organization became a gathering place among Madurese for a variety of activities such as lecturing, the circumcision ceremony, wedding, and other events (Slamet, interviewed on March 12, 2016). Core dimension of social capital lies in the ability of people (nation) to cooperate to build a network in order to achieve a common goal which is characterized by a pattern of interrelations of reciprocity and mutual benefit, and is built on trust, norms, and values (Cahyono and Adhiatma 2012, p.142).

The development of Madura barbershops from year to year are changing. Based 
on the results of the study, it can be summarized that aspects of changing from 1990 - 2015 are the aspects of distribution, shaver, barbers, income, price, the number of the barbershop, customers, and competition in Makassar. For more detail, it can be seen in the following table 2.

The development of barbers as a profession in Makassar becomes the main attraction for the citizens of other Madurese to come and work in the informal sector in Makassar. The implication is the emergence of settlements or Madurese in Makassar that they call tanean naked (a collection of some of the houses that has long front pages). They stay together because they are relatives. There is a family relationship so that kinship is unyielding. Based on the search findings, it is found that Madura community in Makassar lives in the area of Kokolojia, Maradekayya, North Veterans and Antang areas, and they have been about $390 \mathrm{KK}$ (families) (Data PERKIM 2015). Social networks formed into social relations that are bound on the basis of kinship are almost equal to the research findings proposed by Syukur (2016) about the social network of Weaver which was found in Bugis Wajo in South Sulawesi. In his article, Syukur states that there are social relations of Weaver that bound the basic identity of kinship, race, ethnicity, friendship, environment, or specific economic interests. The network of social relations which is developed is based on proximity of residence, kinship, social, economy, and culture (Mudana 2012, p.39).

Social capital is a social institution that consists of trust, norms and networks that promotes social collaboration or social network ties that exist in society. Social capital network has led people to earn extra income so that Madurese are experiencing social transformation of social relations. They formed long-term social networks which are tinged with feelings of obligation toward others, as stated by Sunyoto (2009, p.10). In his research, he found that social capital emphasizes the importance of the transformation of social relations which is momentary and fragile such as neighbor-

Table 2. The dynamics of the Madura barbers in Makassar

\begin{tabular}{|c|c|c|}
\hline $\begin{array}{c}\text { The aspects of } \\
\text { Changing }\end{array}$ & $\begin{array}{l}\text { Changing Condition from } 1990 \\
-2000 \\
\end{array}$ & $\begin{array}{l}\text { Changing Condition from } 2000 \\
-2015\end{array}$ \\
\hline Distribution & It was centered in the city & It began to spread to the suburbs \\
\hline Shaver & $\begin{array}{l}\text { rtially, barbers are still using } \\
\text { inual tools (gothok) }\end{array}$ & $\begin{array}{l}\text { ad already used scissors } \\
\text { clipper) }\end{array}$ \\
\hline Barbers & $\begin{array}{l}\text { nior barbers have a strong influ- } \\
\text { ce, and the junior barbers are } \\
\text { yal to the senior barbers }\end{array}$ & $\begin{array}{l}\text { Young generations of the barbers } \\
\text { are dominant and they are brave } \\
\text { to open new barbershop }\end{array}$ \\
\hline $\begin{array}{l}\text { The Pla } \\
\text { the Bar }\end{array}$ & barbers are still living at rent & $\begin{array}{l}\text { Most barbers are already living in } \\
\text { their own house }\end{array}$ \\
\hline Income & $\begin{array}{l}\text { IDR.30.00o,-- IDR.80.00o,- } \\
\text { ay }\end{array}$ & $\begin{array}{l}\text { AboutIDR. 200.0oo,- - IDR. } \\
\text { 6oo.ooo,- Per Day }\end{array}$ \\
\hline $\begin{array}{l}\text { Price } \\
\text { Number of bar- }\end{array}$ & $\begin{array}{l}\text { DR. } 5.000-\text { IDR. 8.000,- } \\
\text { ed at } 200\end{array}$ & $\begin{array}{l}\text { About IDR. 8.0oo,- - IDR. } 15.000,- \\
\text { It grew rapidly into more than } 300\end{array}$ \\
\hline Cust & $\begin{array}{l}\text { er segment is fixed, and it } \\
\text { be stable and homoge- }\end{array}$ & $\begin{array}{l}\text { Cus } \\
\text { the }\end{array}$ \\
\hline Com & $\begin{array}{l}\text { Business competition has not } \\
\text { been competitive }\end{array}$ & $\begin{array}{l}\text { Competition is getting tougher } \\
\text { and competitive }\end{array}$ \\
\hline $\begin{array}{l}\text { Social organiza- } \\
\text { tion }\end{array}$ & $\begin{array}{l}\text { Joining the organization is based } \\
\text { on kinship as a place to gathering }\end{array}$ & $\begin{array}{l}\text { Social organizations has been } \\
\text { used as a social forum for the peo- } \\
\text { ple of Madura in Makassar }\end{array}$ \\
\hline
\end{tabular}

Source: Adapted from the research results, 2016 and secondary data (Sobiyin, 2014) 
hood, friendship, kinship, to be a long-term relationship that is marked by the emergence of obligation to others. Social capital for Madurese barber is something related to one another, whether economic, cultural, and other forms of social capital of local institutions. Social capital refers to aspects of social organization, such as trust, norms, and social networks that facilitate collective action (Kusumastuti 2012, p.85). These three aspects of social capital affect the development of social relations of Madura barbers in Makassar. Social capital in the form of informal values or norms that are owned by the Barbers enables the barbers to cooperate. In addition, social networking becomes a resource of social capital which needs to be supported by the trust, care, adherence to norms and organizations (Fukuyama 2005; Coleman 1988). Indicators to measure the level of social capital in society are viewed from social networks or work, trust, observance of the norms, concern for others, and involvement in social organizations.

\section{The role of human capital for Madurese barbers in Makassar}

Human capital can be defined as anything owned by an individual who deals with aspects of knowledge, experience, skills, creativity, and innovation. The aspects of human capital are described based on the analysis of informants either community leaders of Madurese or Madurese barbers in Makassar.

Aspect of the knowledge acquired by Madurese barbers in Makassar is something that is obtained either through formal or informal education that helps them in performing their job as a barber. Research findings showed that knowledge of the barber is not learned through formal education, although the barbers are graduated from Senior High School and Vocational High School. Madura barbers acquire their knowledge by doing self-learning. They learn from their fellow and from parents who had been working as a barber. The barbers who studied of shaving are preceded by being cleaning service or helping the barbers to provide shaving tools and finally they are brave to choose to work as a barber. There is also a way to help their parents in a barbershop while learning to shave until finally, they can make a barbershop.

The aspect of knowledge is gained by exploiting all the potential of the sensing mainly obtained through the eyes and ears. Madurese barbers utilize their sense to learn informally through self-taught. Knowledge is the human capital aspect of barbers because it has a vital role to compete and thrive. However, on the other hand, some barbers also cannot rely on the aspect of the job as a barber as stated by (H. Suaib, interviewed on March 1, 2016). He said "I became a barber since 1987. I have 4 children and one of my children works as a teacher". Likewise, (H. Samian, interviewed on March 3, 2016) who is the owner of Keramat Barber and who is the elders of Madura have sent their eight children to school, and five of them have been scholars. Knowledge is an understanding of the process of cognitive systems that are owned by individuals, groups, and organization. Human capital (knowledge) and social capital directly affect the improvement of employment (Khoirrini. L and Kartika L 2014, p.249).

Aspect of experience is an aspect in human capital in the form of involvement in obtaining knowledge and skills of a person based on time or a certain period. Based on the research results, it is found that the aspect of experience owned by the Barbers in Makassar has been longstanding with satisfactory results. Mostly, Madura barbers in Makassar have worked as barber over 10 years, and some have already become a barber for 27 years. During 27 years, they have moved for four times because they just rent a place for their barbershop. Experience as a barber by working on a friend or family led them to open a new barbershop by renting a place. Work experience is the benchmark to determine the performance. Experience makes the Madurese barbers in Makassar more dedicated to their profession so that customers can be satisfied with their work. Sometimes, the customer will have to move to the other barbershop because the previous barbershop also moved. Development of a barbershop is required to earn income, and 
therefore employees are required. The availability of employee is to cover a rented place so that in a barber shop, there are usually 2-3 employees. To see whether the barbershop is interesting for customers or not, it can be seen from the number of employees. The employees come from the system of kinship or friendship. Some of the owners and tenants of the barbershops gain their employees by recruiting them from their village (Madura) who still has family relationship.

Aspect of skills is in the form of Madurese barbers' persistence in doing their job. The skill is required by the barbers since the customers also follow trends of fashion or hairstyle. Therefore, Madurese barbers must have the skills to keep following the trend of fashion. Skill is human capital for the barbers because it has a central role to confront the desired model of the customers so that they can compete with other barbers. The barbers' skills are acquired by self-taught. In the barbershop, the new employees that have just come from the hometown (Madura) are educated by making relationships and communications with friends who had long lived in Makassar. The researcher has found that Madurese in Makassar do not only work as a barber but also as an engineer for shaver (clipper).

Aspect of creativity: creative person being able to make something new is needed This is also true for the babers. Creativity is required because it affects the work performance. The major capital to become a barber is creativity. Knowledge, skills, and experience are very helpful to the barber to be more creative, especially following the development of customer demand for a haircut. Moreover, the competition of barbers is not only from Madurese ethnic, but also from the number of salons which are growing rapidly around the Madura barbershop. Hairstyles are grown so rapidly in line with customer demand which is varied because the customer is not only among the elderly, but they are from all circles, so that the hairstyle should not be monotonous.

Aspect of innovation is also a part of the human capital possessed by the Madurese barber which is defined as a process or a result of the development of the utilization of knowledge, experience, creativity, and skills by using technology. For the first time to be Madurese barbers in Makassar, they still use simple technology (ghotok) in shaving. However, along with the development, the Madurese barbers have already been using technology (clipper). There are some advantages of these tools (clipper). First, the work becomes faster. Second, it is easier to work. Third, it is not to hurt the hand when it is used. Fourth, customers are more satisfied because the results are immaculate (Salahuddin, interviewed on February 27, 2016). Aspects of human capital are used for innovation. Innovation of Madurese barbers is done to satisfy customers based on the customers' request. All Madurese barbershops display photographs of hairstyles that can be chosen by the customer. In addition, the customers can directly communicate with the barber for the desired haircut. Innovation becomes important because it is a human capital that develops according to customer requirements. Innovation becomes the capital as well as the assets that can help business development including barbershop business. Human capital is basically the accumulation of education, skills, and work experience (Yan et al. 2003).

\section{CONCLUSION}

Social capital of Madurese barbers in Makassar consists of some aspects namely trust and norm. People have given trust toward Madurese barbers because they build the trust through a work ethic, belief in attitude, outlook, and guidance in the work (abaranteng). Madurese uphold the norms as Madurese shoreline. The norm is maintained to build the trust of customers, the surrounding community, and the networking aspect. They form social networks of kinship, ethnicity, through the organization of Madurese in Makassar to share customers. The distribution of Madurese barbers in Makassar has reached the suburbs of Makassar. The customers have already fixed and varied, and they are heterogeneous.

Human capital of Madurese barbers in Makassar is based on knowledge gained 
informally by way of self-taught. They learn through the neighborhood fellow and from their parents. Aspect of experience is gained hereditary with satisfactory results. The aspect of skill is needed to improve barbershop business. It is found that in the aspect of creativity the barbers are creative enough to follow the hairstyle and barber economic expansion. In addition, innovation aspect in terms of shaving equipment is already progressing. Initially most barbers used manual shaver (gothok) then it switches to the shaving machine (clipper).

\section{REFERENCES}

Anonim, Arsip PERKIM, 2015. Tidak dipublikasikan.

Berger, P.T. dan Luckmann. T., 1990. Tafsir sosialatas kenyataan; risalah tentang sosiologi pengetahuan. Terjemahan H. Basari. LP3ES, Jakarta.

Bourdieu, P., 1986. The forms of capital.dalamHasbullah. J. (Ed). Sosial capital. MR-United Press, Jakarta.

Bunging, B., 2011. Konstruksi sosial media massa. Kencana Media, Jakarta.

Coleman, J.S., 1988. Sosial capital in the creation of human capital. American Journal of Sociology. 24(1), pp.11-30.

Coleman, J.S. 1998. Foundation of social theory. Belknap Press.

Cahyono, B. \& Adhiatma A., 2012.Peran modal sosialdalam peningkatan kesejahteraan masyarakatpetani tembakau di Kabupaten Wonosobo.Proceedings of Conference In Business Accounting and Management(CBAM). 1(1), pp.131-144.

De Jonge, H., 1989. Madura dalam empat zaman: pedagang, perkembangan ekonomi, dan islam. suatu studi antropologi ekonomi. Gramedia, Jakarta.

Djafar, M., 2010. Etosetnis Madura perantauan di Kota Malang: memahami dialektika agama dengan kearifan lokal. Malang: Fakultas Ekonomi UIN Maulana Malik Ibrahim.

Fukuyama, F., 2005. Goncangan besar: kodrat manusia dan tata sosial baru. Terjemahan M. Maris. Gramedia Pustaka Utama, Jakarta.

Kamarni, N., 2012. Analisis modal sosial sebagai salah satu upaya dalam pengentasan kemiskinan (studikasus: rumah tangga miskin di Kecamatan Koto Tangah Kota Padang). Jurnal Manajemen dan Kewirausahaan, 3(3), pp.3652.

Khoirrini.L. \& Kartika. L., 2014. Pengaruh modal insandan modal sosial terhadap kinerja (studi kasus usaha kecil dan menengah (UKM) makanan dan minuman Kota Bogor). Jurnal Manajemendan Organisasi.5(3), pp.245-257.

Kusumastuti. A., 2012. Modal sosial dan mekanisme adaptasi masyarakat pedesaan dalam pengelaolaan dan pembangunan infrastruktur. Jurnal Sosiologi, 2o(1), pp.81-97.

Miles, M.B. dan Huberman, A.M., 1984. Qualitative Data Analysis A Sourcebook of New Methods. Sage Publication, Beverly Hilld, London, New Delhi.

Mudana, I.W., 2012. Modal sosial dalam pengintegrasianetnis Tionghoa pada masyarakat Desa Pakraman di Bali. Jurnal Ilmu Sosial dan Humaniora, 1(1), pp.30-40.

Muthmainnah. 1998. Jembatan Suramadu: respon ulamater hadap industrialisasi. LKPSM NU, Yogyakarta.

Moleong, L.J., 1989. Metode Penelitian Kualitatif. RamadjaKarya, Bandung.

Parwitaningsih. 2010. Modal sosialdan modal manusia pada pendidikan jarak jauh di Universitas Terbuka. Jurnal Pendidikan Terbuka dan JarakJauh, 11(1), pp.26-34.

Pontoh, O., 2010. Identifikasi dan analisis modal sosial dalam rangka pemberdayaan masyarakat nelayan Desa Gangga Dua Kabupaten Minahasa Utara. Jurnal Perikanan dan KelautanTropis, 6(3), pp.125- 133 .

Pranadji. T., 2006. Penguatan modal sosial untuk pemberdayaan masyarakat pedesaan dalam pengelolaan agroekosistem lahan kering. Jurnal Agro Ekonomi, 24(2), pp.178-206.

Puspitasari, D.C., 2012. Modal sosial perempuan dalam peran penguatan ekonomi keluarga. Jurnal Pemikiran Sosiologi, 1(2), pp.69-8o.

Putnam, R.D., 1993. The prosperous community: social capital and public life Putnam.

Rifai, M.A., 2007. Manusia Madura: Pembawaan, perilaku, etoskerja, penampilan, dan pandangan hidupnya seperti dicitrakan peribahasanya. Pilar Media, Yogyakarta.

Syahra, R., 2003. Modal sosial: konsep dan Aplikasi. Jurnal Masyarakat dan Budaya, 5(1), pp.1-21.

Syamsuddin. M., 2007. Agama, migrasi dan orang Madura. Aplikasia, Jurnal Ilmu-ilmu Agama, 7(2), pp.150-187.

Sunyoto, Y., 2009. Kajian modal sosial dalam pengentasan kemiskinan. Jurnal Litbang Provinsi Jawa Tengah, 7(2), pp.1 - 10.

Syukur, M., 2016. Social network of Bugisweafers at Wajo, South Sulawesi. Komunitas: International Journal of Indonesian Society and Culture. 8(1), pp.155 - 168.

Sobiyin. 2014. Dinamika kehidupan tukang cukur Madura di Kota Makassar; studi sejarah sosialekonomi 1990-2010. Tesis. Program Pascasarjana Universitas Negeri Makassar, Makassar.

Wiyata, A.L., 2013. Mencari Madura. Bidik -Phronesis Publishing, Jakarta.

Yan.W. \& Yudong, Y., 2003. Sources of China's economic growth 1952-1999: incorporating human capital accumulation. Washington DC. China economic review, 14, pp.32-52. 